\title{
ENDIVIDAMENTO PÚBLICO EM MUNICÍPIOS DO ESTADO DE MINAS GERAIS: UMA ANÁLISE DE DADOS EM PAINEL
}

\author{
PUBLIC DEBT IN MUNICIPALITIES OF THE STATE OF MINAS GERAIS: A PANEL DATA \\ ANALYSIS
}

\section{ENDEUDAMIENTO PÚBLICA EN MUNICIPIOS DEL ESTADO DE MINAS GENERALES: UN ANÁLISIS DE DATOS EN PANEL}

Recebido em: 26/06/2017

Avaliado em: 28/11/2018

Reformulado em:19/06/2019

Aceito para publicação em: 03/07/2019

Publicado em: 30/11/2019

Editor Responsável: Marcia Zanievicz da Silva

\author{
Monique da Silva Santana ${ }^{1}$ \\ Walmer Faroni ${ }^{2}$ \\ Nálbia de Araújo Santos ${ }^{3}$ \\ Francisco Carlos da Cunha Cassuce ${ }^{4}$
}

\section{RESUMO}

Este estudo teve por objetivo verificar a relação entre variáveis financeiras com o grau de endividamento de municípios do estado de Minas Gerais. Foram coletadas informações nas bases de dados do Finbra e do Índice Mineiro de Responsabilidade Social/Fundação João Pinheiro (IMRS/FJP) do período de 2005 a 2016. Para a análise dos dados, foi utilizada a técnica de dados em painel com estimação em efeitos fixos. Os resultados apontaram que as variáveis de estrutura de receitas participação da receita tributária e participação na receita do Fundo de Participação do Município (FPM) - afetam positivamente o grau de endividamento dos municípios analisados. $\mathrm{O}$ efeito das variáveis gastos com pessoal e despesas com investimentos foi positivo no endividamento dos municípios do estado de Minas Gerais. Além dessas variáveis, o indicador endividamento defasado também apresentou relação positiva e significativa com o endividamento municipal. Quanto ao tamanho dos municípios, por meio das dummies foi possível observar que o porte populacional não apresentou relação significativa com o endividamento. Isso é confirmado pela estratificação populacional proposta neste estudo, onde $76,3 \%$ dos municípios analisados no período temporal de 2005 a 2016 foram classificados no estrato de baixo endividamento, ou seja, municípios de diferentes portes populacionais compõem o mesmo estrato. Conclui-se, portanto, que o endividamento público é um tema preocupante e considerado um dos principais problemas macroeconômicos enfrentados pelo país.

Palavras-chave: Endividamento Público; Descentralização Fiscal; Lei de Responsabilidade Fiscal.

\footnotetext{
${ }^{1}$ Mestre em Administração pela Universidade Federal de Viçosa (UFV); E-mail: monique.santana@ufv.br

${ }^{2}$ Doutor em Administração pela Universitat de València (UV); Professor Titular do Departamento de Administração e Contabilidade da Universidade Federal de Viçosa (UFV); E-mail: w.faroni@ufv.br

${ }^{3}$ Doutora em Controladoria e Contabilidade pela Universidade Federal de São Paulo (USP); Professora no Programa de Pós-Graduação em Administração Pública em Rede Nacional (Profiap) da Universidade Federal de Viçosa (UFV); Email: E-mail: nalbia@ufv.br

${ }^{4}$ Doutorado em Economia Aplicada pela Universidade Federal de Viçosa (UFV); Professor do Departamento de Economia da Universidade Federal de Viçosa (UFV); E-mail: francisco.cassuce@ufv.br
} 


\section{ABSTRACT}

This study aimed to verify the relationship between financial variables and the degree of indebtedness of municipalities in the state of Minas Gerais. Data were collected from the Finbra and Mineiro Social Responsibility Index/João Pinheiro Fundation (IMRS/FJP) databases for the period from 2005 to 2016. Data analysis was performed using panel data with fixed effects estimation. The results showed that the variables of revenue structure: share of tax revenue and share of Municipal Participation Fund (FPM) revenue positively affect the level of indebtedness of the municipalities analyzed; the variables participation of the ICMS quota and voluntary transfers affect negatively the degree of indebtedness of the municipalities of the sample, but were not statistically significant. The effect of the variables spent on personnel and investment expenses was positive in the indebtedness of the municipalities of the state of Minas Gerais. In addition to these variables, the lagged debt indicator also showed a positive and significant relationship with the municipal indebtedness. As for the size of the municipalities, through the dummies it was possible to observe that the population size did not present significant relation with the indebtedness. This is confirmed by the population stratification proposed in this study, where $76.3 \%$ of the municipalities analyzed in the temporal period from 2005 to 2016 were classified in the low-debt stratum, that is, municipalities of different population sizes make up the same stratum. Concludes, public indebtedness is a worrying issue and considered one of the main macroeconomic problems facing the country.

Keywords: Public indebtedness; Fiscal Decentralization; Tax Responsibility Law.

\section{RESUMEN}

Este estudio tuvo como objetivo verificar la relación entre variables financieras con el grado de endeudamiento de municipios del estado de Minas Gerais. Se recolectar informaciones en las bases de datos de Finbra y del Índice Mineiro de Responsabilidad Social/Fundación João Pinheiro (IMRS/FJP) para el período de 2005 a 2016. Para análisis de los datos, se utilizó la técnica de datos en panel con estimación a efectos fijos. Los resultados apuntaron que las variables de estructura de ingresos: participación de los ingresos tributarios y participación en los ingresos del Fundo de Participación del Município (FPM) afectan positivamente el grado de endeudamiento de los municipios analizados; las variables participación de la cuota ICMS y en las transferencias voluntarias afectan negativamente el grado de endeudamiento de los municipios de la muestra, sin embargo no fueron estadísticamente significativas. El efecto de las variables gastos con personal y gastos con inversiones fue positivo en el endeudamiento de los municipios del estado de Minas Gerais. Además de esas variables, el indicador endeudamiento desfasado también presentó relación positiva y significativa con el endeudamiento municipal. En cuanto al tamaño de los municipios, por medio de las dummies fue posible observar que el porte poblacional no presentó relación significativa con el endeudamiento. Esto es confirmado por la estratificación poblacional propuesta en este estudio, donde el 76,3\% de los municipios analizados en el período temporal de 2005 a 2016 fueron clasificados en el estrato de bajo endeudamiento, o sea, municipios de diferentes portes poblacionales componen el mismo estrato. Se concluye, el endeudamiento público es tema preocupante y considerado uno de los principales problemas macroeconómicos enfrentados por el país.

Palabras clave: Endeudamiento Público; Descentralización Fiscal; Ley de Responsabilidad Fiscal.

\section{INTRODUÇÃO}

Após a redemocratização do país, período pós-Constituição Federal de 1988, com a descentralização das atividades públicas, a crescente demanda dos cidadãos por serviços de qualidade e o elevado custo para manutenção das atividades, os entes da federação passaram a evidenciar um crescimento da dívida pública. Com relação ao nível de endividamento dos governos subnacionais (Estados e Municípios), no período de 1994 a 2003, a dívida líquida passou de 10\% para 18\% em 
relação ao PIB nacional, representando um aumento de 80\%. Para Nascimento e Debus (2002), esse endividamento desproporcional desenhou-se a partir da descentralização fiscal, que gerou aumento nas despesas públicas, sem a contrapartida do incremento das receitas próprias dos municípios brasileiros.

Em relação à receita, a discussão está voltada aos efeitos que as transferências intergovernamentais exercem no desempenho fiscal dos municípios, apesar do efeito positivo sobre os desequilíbrios fiscais entre as regiões. Nesse contexto, e segundo os resultados obtidos no estudo de Corbari (2008), as transferências exercem efeito negativo sobre o desempenho fiscal dos governos receptores, causando a redução no seu esforço fiscal e expandindo os gastos.

Quanto às despesas, o problema concentra-se em torno da ausência de definição clara das competências e atribuições de cada governo, uma vez que a descentralização das responsabilidades públicas não acompanhou o processo de descentralização dos recursos (Rezende, 2001; Tristão, 2003; Corbari, 2008). Diante da demanda social e da falta de oferta por parte do Governo Federal, de determinados bens e serviços, os governos subnacionais foram forçados a assumirem responsabilidades, principalmente nas áreas de saúde e educação, aumentando os seus gastos, com tais serviços (Giambiagi, \& Além, 2000). Como resultado, o período pós-descentralização fiscal foi marcado por elevação das dívidas dos entes da federação.

Considerando a seriedade do problema de endividamento público, algumas medidas de ajuste e de fiscalização foram sendo adotadas nas décadas de 1990 e 2000 (Lima, 2011). Dentre as medidas de ajuste estrutural adotadas pelo governo destaca-se a Lei Complementar $\mathrm{n}^{\circ} 101$, promulgada em 04 de maio de 2000, conhecida como Lei de Responsabilidade Fiscal (LRF). A referida lei visa disciplinar a gestão das finanças públicas em todos os seus níveis de governo, estabelecendo limites para gastos com pessoal, para seguridade social e outras, renúncias de receitas, dívidas consolidadas e mobiliárias, operações de crédito, inclusive por antecipação de receita, concessão de garantia e inscrição em restos a pagar.

Conforme Nascimento e Debus (2002), a LRF foi elaborada para atender às expectativas da sociedade brasileira em busca da responsabilidade e do bom uso dos recursos públicos. Todavia, após mais de uma década de vigor da LRF, o cenário econômico e financeiro brasileiro apresenta desequilíbrio nas contas públicas. Em janeiro de 2019, segundo dados do Banco Central (BACEN, 2019), a dívida líquida do setor público (DLSP) alcançou o patamar de $R \$ 3.733,5$ bilhões, o que representa 54\% do PIB. A dívida bruta do governo geral (DBGG), que compreende o Governo Federal, o Instituto Nacional do Seguro Social (INSS) e os governos estaduais e municipais alcançou o valor de R\$ 5.302,7 bilhões, o equivalente a 76,7\% do PIB. Contribuíram para essa evolução as emissões líquidas de dívida do governo geral, a incorporação de juros nominais, a valorização cambial e o crescimento do PIB nominal. Em relação ao mesmo período do ano anterior a DBGG apresentou expansão de 2,2 pontos percentuais.

No contexto subnacional, o descontrole das contas públicas é nítido em estados como Rio de Janeiro, Rio Grande do Sul e Minas Gerais, que nos anos de 2015 e 2016 declararam calamidade pública no âmbito financeiro. O mais recente foi o estado de Minas Gerais, sendo que o governador do estado, à época, declarou redução significativa na receita pública estadual, dificultando o pagamento dos servidores e a manutenção da prestação dos serviços básicos e essenciais à população. O decreto de calamidade pública financeira prevê que regras da Lei de Responsabilidade Fiscal sejam flexibilizadas por condições atípicas. Em 2017, esses estados apresentaram um endividamento acima de $200 \%$, acrescentando ainda o estado de São Paulo. Nos demais estados brasileiros, para o mesmo período, o endividamento variava entre $30 \%$ a $130 \%$, aproximadamente.

Alguns estudos buscaram identificar o comportamento do endividamento público após a implementação da Lei de Responsabilidade Fiscal (Costa, 2008; Macedo, \& Corbari, 2009; Mello, \& Slomski, 2009; Carvalho, Oliveira, \& Santiago, 2010; Lima, 2011; Mello, 2012; Soares et al., 2013). Todavia, esses estudos focaram o contexto dos estados e de grandes municípios. Com isso, observase, ainda, a existência de lacuna pouco explorada acerca dos fatores associados ao endividamento 
público, no contexto após a LRF, em municípios de diferentes portes populacionais. Dessa forma, o trabalho se propõe a responder o seguinte problema: quais os principais determinantes do endividamento público nos municípios do estado de Minas Gerais no período de 2005 a 2016? Esperase que, após mais de uma década da data de implementação da LRF, os municípios mineiros estejam enquadrados dentro dos limites fixados pela Lei.

Diante do contexto apresentado e da situação de calamidade financeira declarada pelo estado de Minas Gerais no ano de 2016, objetiva-se com este estudo verificar a relação entre variáveis financeiras com o grau de endividamento de municípios do estado de Minas Gerais. Este estudo não focará apenas nos grandes municípios, mas também nos pequenos e médios municípios. Ressalta-se que os menores tendem a ser altamente dependentes de recursos de outras esferas de governos e, possivelmente, podem apresentar elevados níveis de endividamentos para que possam ofertar os serviços básicos necessários à população. Com isso, este estudo permite classificar os municípios quanto ao tamanho e ao grau de endividamento, bem como verificar os reflexos de indicadores financeiros no nível de endividamento municipal por diferentes estratos populacionais.

Especificamente, o objetivo é classificar os municípios mineiros quanto ao grau de endividamento e verificar a relação refletida pelos indicadores no nível de endividamento municipal, observando os municípios por estratos populacionais com base na estratificação proposta pelo Instituto Brasileiro de Geografia e Estatística (IBGE). A relevância do problema acima citado fica mais explicita quando se observa que o estado de Minas Gerais obteve a pior classificação na nota de avaliação de risco, que foi realizada pelo Tesouro Nacional em 2015. Este dado permite inferir o descontrole financeiro enfrentado pelo estado e os desafios da gestão para que possa reverter a situação econômica e financeira.

Este artigo foi estruturado com esta introdução e mais quatro tópicos. A revisão de literatura aborda sobre os temas da descentralização fiscal e os determinantes para o endividamento público. A seção da metodologia apresenta as fontes dos dados e a operacionalização e tratamento dos dados, conforme procedimentos econométricos adotados. É seguida pela seção de resultados e discussões, em que os municípios foram classificados quanto ao grau de endividamento. Por fim, foram apresentadas as conclusões do estudo.

\section{REVISÃO DE LITERATURA}

No Brasil, as finanças públicas são disciplinadas, especialmente, pela Constituição Federal de 1988, pela Lei 4.320/64 e pela Lei Complementar $n^{\circ}$ 101/2000 - a Lei de Responsabilidade Fiscal. Esses normativos estabelecem as linhas de atuação de todas as esferas de governo, principalmente, quanto ao planejamento das receitas e despesas públicas que constituem o orçamento público. A principal preocupação, portanto, está relacionada com a obtenção, distribuição, utilização e controle dos recursos financeiros (Matias-Pereira, 2012).

Nos Estados politicamente organizados em sistemas federativos, as diversas unidades federadas compartilham a responsabilidade pela gestão das funções que cabem ao setor público, quais sejam: alocativa, distributiva e estabilizadora (Musgrave, \& Musgrave, 1980). Para Silva (2005), a principal questão quanto à organização de um sistema fiscal é a clareza e precisão das competências de cada ente federado. Segundo o autor, quanto à função alocativa, entende-se que a autonomia, do ponto de vista técnico-normativo, deve ser compartilhada entre os diferentes níveis de governo visando atender às preferências e às necessidades de cada localidade.

No que se refere à função distributiva, a teoria do federalismo fiscal as tratam como preferencialmente nacionais. As disparidades regionais implicam em diferentes níveis de desenvolvimento na federação, o que gera desigualdade nas oportunidades e possibilidade de escolha entre os indivíduos, regiões e setores. Em resposta a esse cenário desigual é que surge a necessidade de ações econômicas complementares de iniciativa do setor público governamental, em prol da redução das diferenças regionais em termos de renda e qualidade de vida (Silva, 2005). De outra 
forma, está associada a ajustes na distribuição de renda que permitam a prevalência daquela considerada justa pela sociedade (Musgrave, \& Musgrave, 1980).

Ainda, Silva (2005) destaca que a função estabilizadora, assim como a distributiva, é considerada competência primordial da esfera central de governo. As políticas fiscais estabilizadoras, sejam restritivas ou expansivas, quando adotadas isoladamente por governos subnacionais acabam parcialmente anuladas pelo transbordamento decorrente de diversos fatores entre as jurisdições desse Estado Federal. A participação dos entes subnacionais na política estabilizadora é desejável, desde que os procedimentos adotados sejam articulados e coordenados pelo governo central (Silva, 2005). Assim sendo, Cavalcanti (2006) destaca como objetivo da função estabilizadora o uso da política econômica visando manter altos níveis de emprego e a estabilidade dos preços.

A descentralização fiscal no Brasil tem como marco a Constituição Federal de 1988, que foi responsável por conceder maior autonomia política, administrativa e financeira aos Estados e Municípios, principalmente, aos municípios que passaram a ser reconhecidos como entes federativos (Baião, 2013). Para Giambiagi e Além (2000), descentralização significa definir qual ente federativo pode administrar de maneira mais eficiente as obrigações e funções públicas. Já Orair e Alencar (2010) ressaltam que a descentralização fiscal pode gerar ineficiência nas diferentes esferas governamentais, isso devido a uma má distribuição dos recursos, concentração de renda em determinadas áreas, desequilíbrios regionais, dentre outros. Nesse sentido, surgem as transferências intergovernamentais como forma de complemento aos recursos próprios dos governos subnacionais, visando à correção de possíveis desequilíbrios entre os entes federados e esferas de governo.

$\mathrm{O}$ atual sistema de transferências no Brasil tem como característica o fluxo vertical para baixo de recursos, ou seja, o governo federal faz transferências para estados e municípios, ao passo que os estados, por sua vez, transferem recursos aos seus municípios. Essas transferências são de suma importância devido aos desequilíbrios financeiros entre receitas e despesas que possam existir em consequência dos diferentes graus de desenvolvimento econômico entre as regiões do país e aspectos geográficos naturais que beneficiam determinadas localidades em detrimento de outras (Tristão, 2003).

Todavia, alguns autores (Tristão, 2003; Nascimento, 2003; Siqueira, 2014) tratam o montante de transferências como influenciador da ineficiência da administração tributária, causando o desinteresse de arrecadação tributária municipal. Isso porque os governantes veem a possibilidade de minimizar o ônus político causado pela cobrança de tributos dos seus eleitores, tornando as transferências a principal fonte de financiamento dos gastos municipais.

Para Mendes (2002), os gastos com serviços públicos que ficaram a cargo dos governos locais são, na prática, muito maiores que as receitas que esses governos podem obter por meio da arrecadação própria. Esse desequilíbrio fiscal, decorrente da descentralização fiscal, contribuiria para o aumento do endividamento desses governos subnacionais. Além disso, conforme Costa (2008), a sociedade pressionaria os governos locais pela expansão dos gastos públicos em prol do atendimento de suas necessidades, favorecendo o déficit fiscal.

Para os autores Gremaud e Toneto Jr (2002), o endividamento público é um importante mecanismo de gestão de recursos e instrumento de política financeira, que possibilita aumentar a flexibilidade orçamentária, antecipar receitas e a continuidade das despesas, permitindo uma distribuição equânime ao longo do ano. Desse modo, o endividamento é favorável para financiamentos de despesas de capital, uma vez que os benefícios são distribuídos ao longo do tempo e a dívida permite distribuir seu ônus, compatibilizando consumo e pagamento do serviço.

No entanto, o endividamento público que inicialmente era utilizado para viabilizar o desenvolvimento econômico passou, a partir da descentralização fiscal, a atuar de forma prejudicial para as finanças públicas (Garselaz, 2000). Para tanto, a gestão fiscal dos entes da federação deve estar pautada no equilíbrio orçamentário a fim de evitar a geração de déficits e dívidas públicas. Portanto, o endividamento público é um fator recorrente e preocupante no cenário atual do país. 


\subsection{Endividamento público e seus determinantes}

O endividamento público é decorrente de despesas superiores às receitas do ente público, que se torna possível por meio da concessão de empréstimos de terceiros. Essa concessão pode ocorrer de forma voluntária quando da obtenção de empréstimos diretamente nas instituições bancárias oficiais (Estados ou União) ou no mercado financeiro, onde são acordados juros e encargos financeiros, visando financiar o déficit público; ou de forma involuntária pelo não cumprimento dos prazos com fornecedores ou funcionários públicos, sendo que na maioria dos casos o pagamento em atraso ocorre sem juros e correção monetária (Macedo, \& Corbari, 2009).

O grau de endividamento público pode ser obtido, conforme determina a LRF, pela razão entre a Dívida Consolidada Líquida (DCL) e a Receita Corrente Líquida (RCL). Esse indicador permite identificar o quanto da RCL será necessário para quitar o montante da DCL. Além disso, possibilita verificar se os entes públicos estão obedecendo ao limite de endividamento fixado pela Resolução $\mathrm{n}^{\circ}$ 40, de 2001, do Senado Federal, a qual estabelece, em seu artigo $3^{\circ}, 2,0$ da RCL para os Estados e o Distrito Federal e 1,2 da RCL para o endividamento dos Municípios brasileiros. Assim, após a descentralização fiscal, promovida pela CF (Brasil, 1988), e com a elevação do nível do endividamento público foi necessária a imposição de limitações para o controle do endividamento dos entes federativos. E, em busca de uma gestão responsável, são adotadas práticas de gestão financeira visando a melhor aplicação dos recursos para manter o estado de solvência e de capacidade de novos investimentos dos governos (Suzart, 2013).

Diversos indicadores podem ser utilizados para analisar e explicar o endividamento dos entes públicos como, por exemplo, o índice de Endividamento Defasado. Esses indicadores são descritos nos próximos parágrafos e, em geral, representam fatores financeiros. Foram selecionados nas literaturas disponíveis e já são usualmente públicos. Tais indicadores são propostos pela LRF e por Matias e Campello (2000), e utilizados em pesquisas de autores como Mello e Slomski (2008) e Macedo e Corbari (2009).

O indicador de Endividamento Defasado representa o nível do endividamento do exercício anterior, ou seja, o grau de endividamento de um exercício financeiro pode influenciar o grau de endividamento do exercício subsequente. Por este indicador espera-se uma relação positiva com o endividamento municipal, uma vez que os municípios mais endividados seriam os mais propensos a novos endividamentos para financiar suas atividades (Corbari, 2008).

A variável Participação da Receita Tributária apresenta a relação entre as receitas tributárias e a receita total do município. Espera-se que este indicador possua relação negativa com o endividamento. Quanto maior a disponibilidade de recursos advindos de arrecadação própria, menor será a necessidade em contrair dívidas para arcar com as obrigações da gestão municipal.

A variável Participação na Receita de Capital representa a relação entre as receitas de capital em relação à receita total municipal. Conforme os pressupostos dos autores Albaladejo e Lópes (2005), espera-se uma relação negativa desta variável com o endividamento. Os gastos com investimentos são, em tese, financiados por receitas de capital e, por isso, quanto maior a participação das receitas de capital, menor poderá ser a busca por empréstimos e, consequentemente, menor o endividamento.

O indicador Participação da Receita do Fundo de Participação dos Municípios (FPM) é a relação entre a transferência do FPM e o total das receitas do município. Espera-se uma relação positiva com o nível de endividamento dos municípios, uma vez que este é um indicador de dependência do Governo Federal (Corbari, 2008). De forma semelhante, espera-se que aconteça com as variáveis da Participação da cota parte do Imposto sobre Circulação de Mercadorias e Serviços (ICMS), que é a relação entre a cota parte do ICMS e a receita total, indicando a dependência do Governo Estadual; e a Participação da Transferência Voluntária, que expressa a relação entre os recursos advindos de transferências voluntária/convênios e a receita total do município, que também representa um grau de dependência dos municípios por recursos de outras esferas governamentais. A 
dependência de transferências é vista como fator negativo ao desempenho fiscal dos governos receptores, por causar o desinteresse da arrecadação própria e/ou pela expansão dos gastos públicos do governo, e em decorrência aumentando o endividamento (Corbari, 2008).

$\mathrm{O}$ indicador de Gasto com Pessoal demonstra a parcela das receitas correntes líquidas que foram comprometidas pela administração pública com gastos de pessoal. Segundo a LRF, os gastos com pessoal são compostos pelo somatório dos gastos do ente da federação com ativos, inativos e pensionistas, incluindo os encargos sociais. Presume-se uma relação positiva entre esta variável e o endividamento público municipal, pois quanto maior for os gastos com pessoal, maior poderá ser o grau de endividamento dos municípios, uma vez que grande parte de seus recursos estarão comprometidos com este pagamento, o que reduz os recursos disponíveis para fornecer os serviços básicos à população (Macedo, \& Corbari, 2009).

Por fim, o indicador Despesa de Investimento retrata a relação entre os gastos com investimentos e a receita corrente líquida. Espera-se uma relação positiva entre este indicador e o endividamento, considerando que para maiores gastos com investimento o nível de endividamento seria elevado, pois estes tipos de dispêndios são financiados, geralmente, por operações de crédito de longo prazo, o que proporcionaria um crescimento no endividamento público ou no estoque da dívida (Corbari, 2008).

\subsection{Lei de Responsabilidade Fiscal}

A Lei de Responsabilidade Fiscal (LRF) brasileira foi inspirada por experiências internacionais como as do Fundo Monetário Internacional (FMI), órgão que tem editado e difundido algumas normas de gestão pública; da Nova Zelândia por meio do Fiscal Responsibility Act de 1994; dos Estados Unidos, a partir do Budget Enforcement Act, e da União Europeia, por meio do Tratado de Maastricht (Nascimento, \& Debus, 2002). Além de influências internacionais, a crise fiscal e a necessidade de controle do endividamento dos entes subnacionais, por parte do governo federal, foram alguns dos fatores propulsores a elaboração da LRF.

A LRF tem como finalidade estabelecer normas de finanças públicas em prol da responsabilidade na gestão fiscal. Para tanto, tem como base a ação planejada e transparente na administração pública. A Lei contempla a União, os Estados, Distrito Federal e os Municípios, estando compreendidos o Poder Executivo, o Poder Legislativo (incluindo os Tribunais de Contas), o Poder Judiciário, o Ministério Público e as administrações diretas, fundos, autarquias, fundações e empresas estatais dependentes.

Dentre os objetivos da LRF foi estabelecido, em seu art. $1^{\circ}, \S 1^{\circ}$, a ação planejada e transparente, em que se previnem riscos e corrigem desvios capazes de afetar o equilíbrio das contas públicas, mediante o cumprimento de metas de resultados entre receitas e despesas, e a obediência a limites e condições no que tange à renúncia de receita, geração de despesa com pessoal, da seguridade social, dívidas consolidada e mobiliária, operações de crédito, inclusive por antecipação de receita, concessão de garantia e inscrição em Restos a Pagar.

Nascimento e Debus (2002) asseveram que a dívida pública é o principal problema de ordem macroeconômica enfrentado nos últimos tempos, em todos os níveis de governo brasileiro. Desse modo, a LRF trouxe uma nova noção de equilíbrio às contas públicas, as chamadas "contas primárias", que representam o resultado primário equilibrado. O controle da dívida pública é o propulsor da elaboração de uma lei como a LRF. E o equilíbrio almejado para as contas públicas é o equilíbrio autossustentável, de outra forma, é aquele que prescinde de operações de crédito e, portanto, sem aumento da dívida pública.

A LRF, ao estabelecer parâmetros para as despesas com pessoal, procurou restringir aos entes federativos o espaço de manobra em aumentar as despesas sem observância aos preceitos estabelecidos. Desse modo, conforme art. 19 da referida lei, fica estabelecido o limite dos gastos total com pessoal para cada ente da federação, não podendo exceder o percentual de $60 \%$ da receita corrente líquida no caso dos Estados e Municípios e a 50\% da receita corrente líquida para a União. 
Na esfera municipal, o limite de $60 \%$ estabelecido para gastos com pessoal fica desmembrado em $6 \%$ para o Legislativo (incluindo o Tribunal de Contas do Município, quando houver) e 54\% para o Executivo.

Os gastos públicos referentes às despesas com pessoal constituíam importante fator responsável pelo déficit público. Esse cenário de gastos públicos foi sendo modificado após os limites contidos na LRF.

Quando se trata da dívida pública, a LRF, em seu Capítulo VII, concedeu ao Senado Federal a responsabilidade em fixar os limites globais para o montante da dívida consolidada para todos os entes da federação. A Resolução do Senado Federal (RSF) nº 40, de 2001, estabeleceu em seu art. $3^{\circ}$ que, até 2016, a dívida consolidada líquida não poderia ser superior a duas vezes a Receita Corrente Líquida (RCL) para Estados e Distrito Federal; já para os Municípios o limite foi fixado em 1,2 o valor da RCL.

Para que possa ser cumprida e respeitada, a LRF estabelece, em seu art. 31, os prazos para a recondução do limite do endividamento. Se observada a ultrapassagem do limite da dívida consolidada ao final de um quadrimestre, deverá ser reconduzida a ele ao final dos três subsequentes, reduzindo o excedente em pelo menos $25 \%$ no primeiro. Para os casos de descumprimento do limite estabelecido haverá sanções, como proibição de contratação de crédito e suspensão de transferências voluntárias da União ou do Estado.

Além disso, a LRF exige a definição de metas fiscais anuais e a elaboração de relatórios trimestrais de acompanhamento, estabelecendo mecanismos de controle das finanças públicas em anos eleitorais, além da proibição de socorro financeiro cedido pela União aos estados e municípios (Linhares, Penna, \& Borges, 2013).

Para Matias-Pereira (2006, p. 297), a implementação da LRF visa "aumentar a qualidade das ações de gestão fiscal dos recursos públicos confiados aos agentes da administração pública de todas as esferas de governo e coibir os abusos que provocam danos ou prejuízos ao patrimônio público". Diante disso, a LRF se consagrou como um instrumento de planejamento e controle viabilizando e orientando todos os entes públicos desde a União aos municípios para uma gestão responsável.

\subsection{Estudos Anteriores}

Diante a temática do endividamento público, os pesquisadores têm buscado apresentar estudos para identificar fatores que influenciam o endividamento de estados e grandes municípios. Aqui são descritos alguns trabalhos que fazem suporte para a presente pesquisa.

Costa (2008) objetivou discutir os efeitos da LRF para a redução do endividamento dos 26 municípios brasileiros de capitais, no espaço temporal entre 1999 a 2004. Como resultado, o autor concluiu que a LRF não se confirma como um mecanismo institucional para a redução do endividamento público. Sugeriu que o teto do endividamento está bem acima do endividamento corrente das cidades brasileiras, não impondo nenhuma restrição à dívida corrente das capitais. Os dados sugerem que a LRF foi criada apenas para controlar os municípios mais endividados, sendo destacado São Paulo como o município com o mais alto índice de endividamento.

Diferentemente de Costa (2008), Macedo e Corbari (2009) concluíram que houve mudanças significativas no endividamento de municípios com mais de 100 mil habitantes, no período entre 1998 a 2006, por meio de indicadores como o "endividamento defasado" e a "estrutura de capital", após a LRF. A gestão da dívida e das fontes de recursos passou a ser mais efetiva e a rolagem da dívida deixou de ser uma prática dos municípios, confirmando então a hipótese dos autores de que o endividamento dos municípios analisados foi influenciado pela LRF.

Fernandes (2010) objetivou discutir os reflexos da LRF para a redução do endividamento de municípios brasileiros, analisando se sua implantação, a partir de 2000, teve efeito sobre a redução do endividamento dos 26 municípios brasileiros capitais de estado no período de 1999 a 2004 . Os principais resultados indicaram que a LRF não se confirma como um mecanismo institucional para redução do endividamento público, isso porque o teto do endividamento estava bem acima do 
endividamento corrente das cidades brasileiras, não impondo nenhuma restrição à dívida corrente das capitais.

Mello (2012), por sua vez, objetivou verificar a situação das finanças dos municípios Potiguares após a implantação da LRF, no que se refere à redução do endividamento e ao cumprimento dos limites estabelecidos pela referida lei. O período de análise compreende de 1998 a 2003. O autor conclui que a LRF pode ter cumprido seu objetivo de controlar o avanço do endividamento, devido à fixação de regras e limites. Porém, ao comparar os resultados dos municípios Potiguares com os Paranaenses, Mello (2012) identificou um maior endividamento dos primeiros.

Mello e Slomski (2009) identificaram que fatores relacionados às receitas de transferências, receita per capita, a cobertura corrente total (essa influência ocorre de forma negativa) e o próprio endividamento do período anterior (de forma positiva) são os que mais impactaram o endividamento dos estados brasileiros, no intervalo temporal de 2000 a 2005. De forma complementar, Soares et al. (2013) verificaram que variáveis como as despesas com investimentos, a inflação e também os anos eleitorais são significativas para explicar o comportamento do endividamento dos estados, no período de 2000 a 2010.

Carvalho, Oliveira e Santiago (2010) objetivaram identificar o comportamento do endividamento dos estados nordestinos no período de 2000 a 2007. Na análise dos indicadores de endividamento de curto prazo, os autores supramencionados identificaram uma queda significativa do endividamento ao longo dos anos, demonstrando a influência da LRF e das Resoluções do Senado $n^{\circ} 40$ e 43/2001, que surgiram para reforçar os limites e restrições da atividade pública, principalmente, no que diz respeito ao endividamento público. Concluíram, ainda, que os estados Nordestinos têm buscado o equilíbrio da execução orçamentária, comprometendo o mínimo de suas receitas correntes com dívidas de curto prazo.

Lima (2011) buscou medir e explicar o desempenho do nível da dívida dos grandes municípios brasileiros no período entre 2000 a 2008 em função dos recursos potenciais para servir a dívida e dos mecanismos de restrições orçamentárias. Os achados permitiram inferir que o limite de despesas com pessoal e a destinação da dívida para investimentos são responsáveis para garantir o desempenho do nível da dívida dos grandes municípios brasileiros; os mecanismos de restrições orçamentárias provocam efeitos positivos no nível da dívida desses municípios; e as transferências voluntárias atuam como força contrária ao desempenho do nível da dívida. Além disso, o autor verificou que o limite legal para o endividamento é bastante elevado para os municípios, exceto São Paulo e Rio de Janeiro, haja vista o considerável tamanho populacional desses municípios - fato este que vai de encontro com o resultado apresentado por Costa (2008).

E, por fim, Ferreira et al. (2013) analisaram o comportamento dos governos estaduais na gestão de suas receitas e despesas, e a respectiva influência sobre o nível de endividamento dos estados brasileiros no período de 2000 a 2010. Os autores realizaram estimações da razão dívida consolidada líquida e receita corrente líquida, do resultado primário e do resultado nominal em função da receita tributária, transferências correntes, despesa com pessoal e gastos com investimentos, identificando a influência dessas variáveis sobre os indicadores de endividamento. Os resultados demonstraram que as variáveis foram significativas para explicar o comportamento do endividamento estadual. Todavia, para controlar o endividamento estadual será necessário que o governo dê atenção as transferências correntes, que vão influenciar de forma mais expressiva na redução do nível de endividamento estadual e também no controle das despesas com pessoal que tendem a elevar o nível do endividamento. Ainda, os autores concluíram que os estados brasileiros apresentam a relação DCL/RCL elevada com tendência de crescimento no futuro, ressaltando a importância de um aparato institucional bem formulado para cobrar das administrações maior comprometimento com as finanças públicas. 


\section{PROCEDIMENTOS METODOLÓGICOS}

Este estudo classifica-se como de caráter quantitativo em razão de utilizar de técnicas e análises estatísticas para compreender a relação de indicadores financeiros com o grau de endividamento dos municípios em análise. Além disso, verifica-se o comportamento do endividamento nos municípios do estado de Minas Gerais divididos por estratos populacionais.

O estado de Minas Gerais é constituído por 853 municípios, conforme dados do IBGE, representando $15,3 \%$ dos municípios (5.570) brasileiros. Entretanto, a amostra foi reduzida em razão da indisponibilidade de dados como, por exemplo, o valor da receita tributária, dos valores repassados do FPM, do ICMS e o percentual de gastos com pessoal, que é relevante para cálculo das variáveis, objeto desse estudo. Assim, a amostra compreendeu 523 municípios, representando $61 \%$ do total, no período de 2005 a 2016, e perfazendo um total de 6.276 observações.

Ressalta-se que, para o ano de 2017, 87\% dos municípios de Minas Gerais divulgaram seu indicador de endividamento no valor de 0 , que representaria não endividado. Diante da inconsistência apresentada pelos dados do endividamento dos municípios do estado de Minas Gerais para o ano de 2017, optou-se por não incorporá-lo na análise temporal realizada. Em especial, porque se presume que o volume de valores zero se dá em razão da indisponibilidade da informação, e não devido aos municípios não estarem endividados. A Tabela 1 informa os estratos populacionais para o espaço temporal de 2005 a 2016.

Tabela 1 - Classificação dos municípios mineiros por habitantes.

\begin{tabular}{llccc}
\hline Estrato & Intervalo & $\mathbf{N}^{\mathbf{0}}$ de municípios & $\begin{array}{c}\mathbf{N}^{\mathbf{0}} \text { de municípios } \\
\text { analisados }\end{array}$ & $\begin{array}{c}\text { Municípios } \\
\text { analisados em (\%) }\end{array}$ \\
\hline Pequeno porte I & Até 5.000 & 240 & 116 & 48,3 \\
Pequeno porte II & De 5.001 até 10.000 & 251 & 150 & 59,7 \\
Pequeno porte III & De 10.001 até 20.000 & 184 & 114 & 61,9 \\
Médio porte I & De 20.001 até 50.000 & 112 & 88 & 78,5 \\
Médio porte II & De 50.001 até 100.000 & 37 & 32 & 86,4 \\
Grande porte I & Acima de 100.000 & 29 & 23 & 79,3 \\
\hline Total & & $\mathbf{8 5 3}$ & $\mathbf{5 2 3}$ & - \\
\hline
\end{tabular}

Fonte: Elaborado pelos autores com base em dados disponibilizados pelo IBGE.

Para viabilizar a análise dos estratos populacionais optou-se por criar variáveis binárias ou dummies. Foram criadas cinco variáveis dummies: $D p_{1}$ até $D p_{3}$ para representar os municípios de pequeno porte, em que se assumiu o valor 1 para o intervalo ao qual o município se posiciona e $0 \mathrm{em}$ caso negativo; $D m_{1}$ e $D m_{2}$ para representar os municípios de médio porte, onde as dummies assumem valor 1 para o intervalo ao qual o município se posiciona e 0 em caso negativo.

Para tipificar os municípios do estado de Minas Gerais quanto ao grau de endividamento, classificou-se os municípios analisados em quatro estratos. Com o objetivo de identificar a evolução do grau de endividamento municipal, essa estratificação foi realizada para todo o período em análise (2005 a 2016). O escore utilizado para o agrupamento é apresentado na Tabela 2.

Tabela 2 - Estratificação dos municípios de acordo com o grau de endividamento.

\begin{tabular}{cc}
\hline Grau de Endividamento & Escore \\
\hline Não endividado & $\mathrm{GE}<0$ \\
Baixo & $0 \leq \mathrm{GE} \geq 0,30$ \\
Médio & $0,30<\mathrm{GE}<0,80$ \\
Alto & $\mathrm{GE} \geq 0,80$ \\
\hline
\end{tabular}

Fonte: Dados da Pesquisa.

O grau de endividamento é obtido pela relação DCL/RCL, podendo ter resultado com sinal negativo quando os recursos financeiros disponíveis são superiores e capazes de suprir a dívida consolidada líquida. $\mathrm{O}$ resultado zero ocorre quando os recursos disponíveis são suficientes para 
suprir a dívida e o indicador de endividamento pode ser positivo, quando a dívida consolidada líquida se torna superior aos recursos disponíveis.

O Senado Federal estabelece um limite máximo para o endividamento de 1,2 em relação à receita corrente líquida do município. No entanto, Lima (2011) identificou que esse limite de endividamento é superior a capacidade de endividamento dos municípios, exceto para os municípios de São Paulo e Rio de Janeiro. Diante disso, e da ausência de literatura que apresente uma classificação nominal para o grau de endividamento, justifica-se a classificação aqui proposta.

Quando o foco dos estudos é o endividamento público, diversos indicadores podem ser utilizados para verificar o desempenho financeiro do ente público em questão. Neste estudo, o objetivo é identificar a relação entre indicadores financeiros dos municípios do estado de Minas Gerais com o endividamento público municipal. Para isso, foram coletados dados secundários nas seguintes bases: (i) Finanças do Brasil, Dados Contábeis dos Municípios - FINBRA; (ii) Instituto Brasileiro de Geografia e Estatística; (iii) Índice Mineiro de Responsabilidade Social; e, (iv) Fundação João Pinheiro. O Quadro 1 apresenta as variáveis utilizadas, assim como sua descrição, a relação esperada e o embasamento teórico.

\begin{tabular}{|c|c|c|c|c|c|c|}
\hline Dimensão & Variável & Descrição & Fórmula & Fonte & $\begin{array}{l}\text { Relação } \\
\text { esperada }\end{array}$ & Alguns Estudos \\
\hline \multirow{2}{*}{ 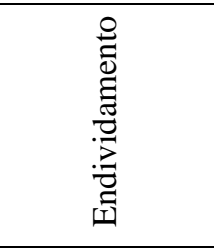 } & GE & $\begin{array}{l}\text { Grau de } \\
\text { Endividamento }\end{array}$ & DCL/RCL & IMRS/FJP & $x^{2}+2-2$ & $\begin{array}{l}\text { Costa (2008); Mello e } \\
\text { Slomski (2008); Lazarin, } \\
\text { Mello e Bezerra (2014); }\end{array}$ \\
\hline & ED & $\begin{array}{l}\text { Endividamento } \\
\text { Defasado }\end{array}$ & $\begin{array}{l}\text { DCL/RCL } \\
\text { Ano } \\
\text { anterior } \\
\end{array}$ & IMRS/FJP & Positiva & $\begin{array}{l}\text { Corbari (2008); Linhares, } \\
\text { Penna e Borges (2013); } \\
\text { Ferreira et al (2013); }\end{array}$ \\
\hline \multirow{2}{*}{ 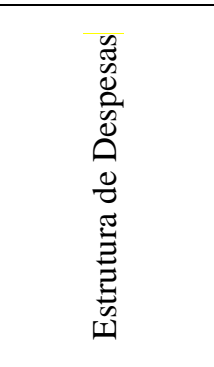 } & GP & $\begin{array}{l}\text { Gasto com } \\
\text { Pessoal }\end{array}$ & $\begin{array}{c}(\mathrm{DP}+\mathrm{ENC}) / \\
\mathrm{RCL}\end{array}$ & IMRS/FJP & Positiva & $\begin{array}{l}\text { Matias e Campello (2000); } \\
\text { Macedo e Corbari (2009); } \\
\text { Gerigk e Clemente (2012); } \\
\text { Ferreira et al (2013); }\end{array}$ \\
\hline & PDI & $\begin{array}{l}\text { Percentual de } \\
\text { despesa com } \\
\text { Investimento }\end{array}$ & DCAP/RCL & FINBRA & Positiva & $\begin{array}{l}\text { Matias e Campello (2000); } \\
\text { Macedo e Corbari (2009); } \\
\text { Mello e Slomski (2009); } \\
\text { Gerigk e Clemente (2012); } \\
\text { Ferreira et al (2013); }\end{array}$ \\
\hline \multirow{4}{*}{ 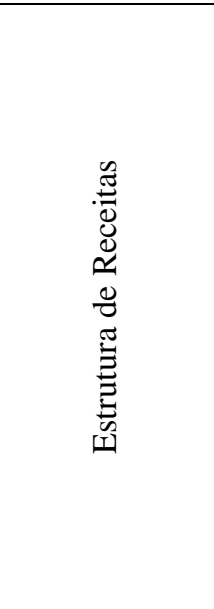 } & PRT & $\begin{array}{l}\text { Participação } \\
\text { da Receita } \\
\text { Tributária }\end{array}$ & $\mathrm{RTB} / \mathrm{RT}$ & FINBRA & Negativa & $\begin{array}{l}\text { Matias e Campello (2000); } \\
\text { Mello e Slomski (2009); } \\
\text { Gerigk e Clemente (2012); } \\
\text { Macêdo, Vesco e Toledo } \\
\text { Filho (2012); }\end{array}$ \\
\hline & PRFPM & $\begin{array}{l}\text { Participação } \\
\text { da Receita do } \\
\text { FPM }\end{array}$ & FPM/RT & FINBRA & Positiva & $\begin{array}{l}\text { Matias e Campello (2000); } \\
\text { Mello e Slomski (2009); }\end{array}$ \\
\hline & PRICMS & $\begin{array}{c}\text { Participação } \\
\text { da cota parte } \\
\text { do ICMS } \\
\end{array}$ & ICMS/RT & FINBRA & Positiva & $\begin{array}{l}\text { Matias e Campello (2000); } \\
\text { Mello e Slomski (2009); }\end{array}$ \\
\hline & PTV & $\begin{array}{l}\text { Participação } \\
\text { das receitas de } \\
\text { Transferência } \\
\text { Voluntária } \\
\end{array}$ & TV/RT & FINBRA & Positiva & $\begin{array}{c}\text { Matias e Campello (2000); } \\
\text { Lima (2011); }\end{array}$ \\
\hline $\begin{array}{l}\text { Característica } \\
\text { Demográfica }\end{array}$ & Dummy & $\begin{array}{l}\text { Dummypara } \\
\text { faixas } \\
\text { populacionais }\end{array}$ & - & IBGE & - & - \\
\hline
\end{tabular}

Fonte: Elaborado pelos autores.

Para atender aos objetivos propostos no trabalho foram realizadas estimações econométricas por meio da técnica de dados em painel. Os modelos de regressão para dados em painel são utilizados quando os dados de indivíduos ou cross-sections (pessoas, empresas, estado e municípios, por 
exemplo) são disponibilizados para mais de um instante de tempo (várias, como semanas, meses ou anos, por exemplo) (Fávero, 2015).

Segundo Gujarati (2006), a técnica de dados em painel apresenta diversas vantagens em relação às que utilizam separadamente dados em corte transversal (várias unidades em um instante de tempo) e à série temporal (uma unidade ao longo do tempo). Dentre as vantagens, o autor cita: i) leva em conta a heterogeneidade entre as unidades analisadas, neste caso os municípios; ii) combinam dados de série temporal e corte transversal, proporcionando o aumento de informações e de variabilidade, além de reduzir a colinearidade entre as variáveis, gerando maiores graus de liberdade e eficiência; e, iii) os dados em painel possibilitam detectar e medir os efeitos melhor do que quando a observação é realizada pelo método de corte transversal ou série temporal.

Para tanto, foi estimado um modelo para captar a relação de indicadores financeiros sobre o grau de endividamento dos municípios mineiros, considerando faixas populacionais. $\mathrm{O}$ modelo pode ser observado na equação (1).

$$
\begin{aligned}
& \quad G E_{i t}=\beta_{0}+\gamma_{1} D p_{1}+\gamma_{2} D p_{2}+\gamma_{3} D p_{3}+\gamma_{4} D m_{1}+\gamma_{5} D m_{2}+\beta_{1} G E_{i t-1}+\beta_{2} P R T_{i t}+\beta_{3} P F P M_{i t}+ \\
& \quad+\beta_{4} P I C M S_{i t}+\beta_{5} P T V_{i t}+\beta_{6} G P_{i t}+\beta_{7} P D I_{i t}+e_{i t} \\
& i=1,2,3 \ldots .523 \\
& t=2005,2006,2007 \ldots . .2016
\end{aligned}
$$

em que, $G E_{i t}$ corresponde ao grau de endividamento do município $i$ no período $t$. O grau de endividamento representa a variável dependente do estudo. Esse indicador pode ser obtido por meio da razão entre a Dívida Consolidada Líquida e a Receita Corrente Líquida, conforme estabelece a LRF; $\beta_{0}$ é o intercepto comum a todos os municípios mineiros; $\gamma_{1}, \gamma_{2}, \gamma_{3}, \gamma_{4}, \gamma_{5}$ medem a influência das variáveis dummies de tamanho; $D p_{1}$ representa a variável dummy para municípios de pequeno porte I; $D p_{2}$ refere-se a variável dummy para as cidades de pequeno porte II; $D p_{3}$ é a dummy para os municípios de pequeno porte III; $D m_{1}$ corresponde aos municípios de médio porte I; $D m_{2}$ é a variável dummy para os municípios de médio porte II; $\beta_{1}, \beta_{2}, \beta_{3} \ldots \beta_{7}$ medem a influência das variáveis relacionadas; $G E_{t-1}$ corresponde ao endividamento defasado do município $i$ no período $t$; $P R T_{i t}$ representa a variável participação da receita tributária na receita total do município $i$ no período $t ; P_{R F P M_{i t}}$ se refere à participação da receita do FPM na receita total do município $i$ no período $t ; P$ ICMS ${ }_{i t}$ indica a parcela da cota do ICMS em relação a receita total do município $i$ no período $t ; P T V_{i t}$ representa a participação da receita de transferência voluntária na receita total do município $i$ no instante $t$; $G P_{i t}$ é o indicador referente ao percentual de gasto com pessoal em relação à receita corrente líquida do município $i$ no período $t$; a variável $P D I_{i t}$ se refere às despesas de investimento em relação à receita corrente líquida do município $i$ no período $t$; e, $e_{i t}$ representa os termos de erro do modelo.

A análise de dados em painel pode considerar os estimadores, a saber: Pooled OLS (POLS), efeitos fixos e efeitos aleatórios, considerando a existência ou não de heterogeneidade entre os municípios do estado de Minas Gerais e a sua natureza. A estimação Pooled pressupõe a base de dados como sendo uma cross-section e, por meio do método de Mínimos Quadrados Ordinários (MQO), estima os parâmetros do modelo proposto. Neste caso, admite-se que não há heterogeneidade entre os municípios admitidos na análise. O modelo de regressão para dados em painel com efeitos fixos supõe a existência de efeitos individuais que representam as heterogeneidades entre os indivíduos e capturam suas diferenças invariantes no tempo. Na estimação por efeitos aleatórios também se assume que há heterogeneidade entre os municípios. Contudo, essa heterogeneidade 
apresentaria característica estocástica e não determinística. Outra diferença entre os estimadores de Efeitos Fixos e de Efeitos Aleatórios é que o primeiro assume que a heterogeneidade entre os indivíduos estaria correlacionada com as variáveis explicativas (Fávero, 2015).

Dessa forma é preciso determinar a heterogeneidade entre os municípios e as características dessa heterogeneidade seria fundamental para que se possa escolher o estimador mais eficiente para gerar o modelo que explicará o endividamento dos municípios mineiros. Para tanto, foram realizados teste estatísticos que pudessem auxiliar na determinação do modelo mais apropriado. Nesse sentido, Fávero (2015) apresenta os seguintes testes: teste de Chow, teste LM (Lagrangemultiplier) e o teste de Hausman. O teste de Chow tem como finalidade identificar se o modelo Pooled é mais apropriado em detrimento do modelo de efeitos fixos. Este teste tem como hipótese nula o fato das unidades de seção cruzada (municípios) serem homogêneas. O teste LM (Lagrangemultiplier) permite verificar se o modelo mais apropriado é o modelo Pooled ou modelo aleatório. Neste caso, a hipótese nula é de que o modelo Pooled é preferível em vez do modelo de efeitos aleatórios. Por fim, o teste de Hausman é utilizado para verificar qual é o modelo mais apropriado entre os modelos de efeito fixo e aleatório. Tal teste parte da hipótese nula de que os efeitos são aleatórios.

Além dos testes para determinar o modelo a ser aplicado, foi realizado o teste de Wald modificado para captar a heterocedasticidade em grupo e o teste de Wooldridge para verificar problemas de autocorrelação. No teste de Wald, a hipótese nula é de que não há heterocedasticidade em grupo. Já o teste de Wooldridge tem como hipótese nula a ausência de autocorrelação. A correção desses problemas pode ser realizada por estimações considerando erros-padrão robustos.

A operacionalização e tratamento dos dados foram realizados por meio do software estatístico Stata - Data Analysis and Statístical Software versão 11.

\section{RESULTADOS E DISCUSSÕES}

Nesta seção são discutidos os resultados das estimações econométricas realizadas por meio da técnica de dados em painel. E, além disso, é apresentada a estratificação populacional proposta nesta pesquisa com base ao grau de endividamento dos municípios do estado de Minas Gerais.

\subsection{Classificação dos municípios quanto ao grau de endividamento}

Para atender aos objetivos propostos neste estudo, os municípios do estado de Minas Gerais foram divididos em quatro estratos, tomando como base a variável grau de endividamento, obtida pela razão DCL/RCL. Na Tabela 3 apresenta-se a distribuição de frequência gerada pela estratificação dos municípios para os anos de 2005 a 2016.

Tabela 3 - Estratos de Endividamento Municipal.

\begin{tabular}{|c|c|c|c|c|c|c|c|c|c|c|c|c|c|c|}
\hline \multirow[t]{2}{*}{ Estrato } & \multirow{2}{*}{$\begin{array}{c}\text { Grau de } \\
\text { Endividamento }\end{array}$} & \multicolumn{12}{|c|}{ Frequência } & \multirow{2}{*}{$\begin{array}{c}\% \\
\text { Total }\end{array}$} \\
\hline & & 2005 & 2006 & 2007 & 2008 & 2009 & 2010 & 2011 & 2012 & 2013 & 2014 & 2015 & 2016 & \\
\hline 0 & Não endividado & 243 & 270 & 292 & 329 & 0 & 0 & 0 & 0 & 0 & 0 & 0 & 0 & 18,1 \\
\hline 1 & Baixo & 234 & 213 & 203 & 179 & 483 & 487 & 490 & 489 & 485 & 500 & 503 & 523 & 76,3 \\
\hline 2 & Médio & 44 & 39 & 26 & 14 & 39 & 35 & 32 & 33 & 37 & 22 & 19 & 0 & 5,4 \\
\hline 3 & Alto & 2 & 1 & 2 & 1 & 1 & 1 & 1 & 1 & 1 & 1 & 1 & 0 & 0,2 \\
\hline
\end{tabular}

Fonte: Resultados da Pesquisa.

Na Tabela 3 é possível identificar que os municípios mineiros analisados, em sua maioria, não apresentam alto grau de endividamento, segundo o critério estabelecido neste estudo e descrito na metodologia. Este estudo estipulou em $80 \%$ da RCL. Em 2005, apenas dois municípios estiveram no estrato de alto endividamento, sendo eles: Contagem e Timóteo. Em 2007, os municípios de Araxá e novamente Timóteo apresentaram-se nesse estrato. Nos demais anos analisados apenas Timóteo se enquadrou no estrato de alto endividamento.

Ainda, é possível notar que os municípios mineiros apresentaram uma concentração no estrato de baixo grau de endividamento, representado por, aproximadamente, 76,3\% do total no período de 
2005 a 2016. Esse estrato era composto por 234 municípios em 2005, passando para 523 no ano de 2016, duas vezes o valor. Esse fato se deu por meio do aumento do grau de endividamento dos municípios. Em 2005, 243 municípios pertenciam ao estrato de não endividado, isso porque os recursos disponíveis eram suficientes para saldar o montante da dívida consolidada líquida. Já no período de 2009 a 2013, nenhum município foi enquadrado nesse estrato.

\subsection{Análise dos determinantes do endividamento de municípios mineiros}

Inicialmente, avaliou-se a existência heterogeneidade entre os municípios da amostra e o tipo de heterogeneidade. Os resultados dos testes de Chow, o do Multiplicador de Lagrange e o teste de Hausman são informados na Tabela 4. Seus resultados possibilitam optar-se pelo estimador de Efeitos Fixos para estimar o modelo que explicaria os determinantes do grau de endividamento entre os municípios selecionados em Minas Gerais.

Tabela 4 - Testes estatísticos realizados para auxiliar a escolha do estimador a ser utilizado

\begin{tabular}{lc}
\hline \multicolumn{1}{c}{ Estatísticas } & Valor Calculado \\
\hline Teste Chow & $1,72 * * *$ \\
Teste Lagrangemultiplier & $3,28^{* * *}$ \\
Teste de Hausman & $726,31^{* * *}$ \\
\hline
\end{tabular}

Fonte: Resultados da pesquisa.

Notas: $* * *$ Significativo a $1 \%$.

Uma vez determinado o tipo de heterogeneidade entre os municípios da amostra, foram realizados testes para verificar a existência de heterocedasticidade e de autocorrelação. Para identificar a presença de heterocedasticidade foi realizado o teste modificado de Wald. A autocorrelação foi verificada por meio do teste de Wooldrigdge. Os resultados apresentados na Tabela 5 indicam que os erros são heterocedásticos e autocorrelacionados, fazendo-se necessário estimar o modelo com erros-padrão robustos a heterocedasticidade e autocorrelação.

Tabela 5 - Testes estatísticos para identificar heterocedasticidade e autocorrelação.

\begin{tabular}{lc}
\multicolumn{1}{c}{ Estatísticas } & Valor Calculado \\
\hline Teste modificado de Wald & $48664.21^{* * *}$ \\
Teste de Wooldrigdge & $524.335^{* * *}$ \\
\hline
\end{tabular}

Fonte: Resultados da pesquisa.

Notas: *** Significativo a $1 \%$

O modelo estimado é apresentado na Tabela 6.

Tabela 6 - Modelo de Efeitos Fixos para analisar a relação de indicadores financeiros no grau de endividamento dos municípios de Minas Gerais, 2005 a 2013.

\begin{tabular}{lccc}
\hline GE & Coeficientes & Erro Padrão & p-valor \\
\hline Dp1 & 6.5477 & $(7.1586)$ & 0.360 \\
Dp2 & 5.7027 & $(7.1883)$ & 0.428 \\
Dp3 & 3.8364 & $(6.8051)$ & 0.573 \\
Dm1 & 2.3421 & $(6.8577)$ & 0.733 \\
Dm2 & 1.2027 & $(6.8602)$ & 0.861 \\
ED & 0.5557 & $(0,0145)$ & 0.000 \\
PRT & 27.7480 & $(7.0054)$ & 0.000 \\
PRFPM & 13.7741 & $(3.7109)$ & 0.000 \\
PICMS & -5.7135 & $(6.4421)$ & 0.375 \\
PTV & -1.5693 & $(4.9707)$ & 0.752 \\
GP & 0.4399 & $(0,0286)$ & 0.000 \\
PDI & 0.6132 & $(0.1892)$ & 0.001 \\
Constante & -31.0899 & $(6.9914)$ & 0.000 \\
\hline
\end{tabular}

Fonte: Resultados da pesquisa.

Os resultados indicam que as variáveis dummys de tamanho não foram significativas para explicar o grau de endividamento, ou seja, os municípios podem apresentar elevado grau de endividamento independente do seu porte. Isso é confirmado pela estratificação proposta no presente 
trabalho, em que se identificou uma concentração de municípios com baixo grau de endividamento (entre 0 e 0,30 , nesta pesquisa) independente do porte populacional.

O indicador GE t-1 (endividamento defasado) apresentou relação positiva e significativa com o endividamento municipal, ou seja, quanto maior no nível de endividamento do exercício anterior, mais propenso estará o município à aquisição de novos endividamentos nos exercícios subsequentes - fato este também confirmado no estudo de Corbari (2008).

A variável PRT apresentou relação positiva com o grau de endividamento, ou seja, quanto maior for a participação de receita tributária do município na receita total, maior será o grau de endividamento. Essa relação positiva entre a variável PRT e o grau de endividamento contraria o estudo de Ferreira et al. (2013). Os autores concluíram que o problema do endividamento dos estados pode ser controlado por meio de uma política que aumente a arrecadação de recursos próprios, por meio de fiscalização que iniba a ocorrência de inadimplentes. O que se esperava é que os municípios que apresentam maior relação de receitas próprias apresentariam menor grau de endividamento; no entanto, presume-se que a relação positiva encontrada pode ser decorrente das demandas sociais. Sendo assim, aqueles que possuem maior percentual de arrecadação própria seriam também aqueles que possuem maior volume de gastos com serviços básicos necessários a população.

Quanto às variáveis de dependência de recursos, o indicador que representa a participação da receita do FPM na receita total do município se mostrou positivo ao grau de endividamento. Esse resultado confirma as expectativas do estudo. Pressupõe-se que a relação de dependência de recursos de esferas intergovernamentais (PRFPM, PICMS e PTV) refletiria em um maior grau de endividamento, isso porque a dependência de recursos é vista como um fator negativo ao desempenho fiscal dos governos receptores (Siqueira, 2014). De outra forma, as transferências intergovernamentais podem ter relação com o desincentivo da arrecadação própria, influenciando negativamente o grau de esforço fiscal dos municípios (Orair, \& Alencar, 2010). Consequentemente, a relação positiva da dependência do FPM com o grau de endividamento pode ser compreendida, uma vez que municípios mais dependentes de transferências de outras esferas estariam mais propensos ao endividamento para obter recursos e atender às demandas da sociedade.

Ainda sobre a dependência de recursos intergovernamentais, as variáveis participação na cota parte do ICMS e participação de transferências voluntárias na receita total não foram significativas para explicar o grau de endividamento dos municípios do estado de Minas Gerais. Nos trabalhos de Macedo e Corbari (2009) e Linhares, Penna e Borges (2013), a relação de dependência desses recursos de transferências se mostrou negativa ao grau de endividamento, ou seja, quanto maior a dependência dos municípios por esses recursos, menor o endividamento do município. Com isso, os autores verificaram que as transferências intergovernamentais tendem a reduzir a necessidade de os municípios buscarem financiamentos por meio de empréstimos.

No entanto, Lima (2011) concluiu que as transferências voluntárias flexibilizam as restrições orçamentárias, causando uma piora no desempenho da dívida. Isso porque, segundo os achados do autor, os gestores, no momento de tomar decisões sobre operações de crédito, incluem expectativas de ajuda financeira de governos superiores por meio dessas transferências.

Quando a variável em análise passa a ser o gasto com pessoal, a relação com o grau de endividamento dos municípios se torna positiva, ou seja: quanto maior os gastos com pessoal, maior o endividamento do município. Este fato já é esperado, uma vez que parcela considerável dos recursos financeiros do município deverá ser destinada aos salários e encargos com pessoal. Esse resultado também foi evidenciado no estudo de Macedo e Corbari (2009), tendo em vista que elevados níveis de gastos comprometidos com pessoal reduz a disponibilidade de recursos para outras áreas, e com isso há a necessidade de recorrer a outras fontes de recursos como, por exemplo, uma maior utilização de terceiros.

Uma associação positiva também foi encontrada quando se analisa as despesas com investimentos. Os municípios que apresentam esses indicadores mais elevados são mais propensos ao endividamento. Esse fato era esperado e confirma os achados de pesquisas anteriores (Macedo, \& 
Corbari, 2009; Fernandes, 2010; Soares et al., 2013; Ferreira et al. 2013; Linhares, Penna, \& Borges, 2013). Isso é explicado por causa da natureza dessa conta de despesas de investimento, pois estes tipos de dispêndios são financiados, geralmente, por operações de crédito de longo prazo, visando à distribuição do benefício e do ônus dos investimentos. Esse fator faz com que ocorra um aumento no grau de endividamento.

Em relação às duas variáveis que representam os gastos, gasto com pessoal e despesa com investimentos, foi possível observar que a despesa de investimento exerce maior influência sobre o endividamento, se comparado com o gasto com pessoal. Esse resultado se revelou semelhante aos achados de Linhares, Penna e Borges (2013). Estes autores concluíram que as despesas com investimentos exercem uma influência três vezes maior que os gastos com pessoal para os municípios piauienses.

Considerando que os municípios do estado de Minas Gerais da amostra apresentaram heterogeneidade e que essa seria de caráter determinístico, as diferenças não explicadas pelas variáveis do modelo, entre os municípios, poderiam ser captadas pelos efeitos fixos gerados nas estimativas. A Tabela 7 apresenta os efeitos fixos calculados para o grau de endividamento dos municípios analisados, onde a primeira coluna representa a posição dos municípios em termos de efeitos fixos dentre os 523 municípios analisados. Os efeitos fixos calculados são apresentados para 20 municípios, sendo 10 maiores e 10 menores PIB's do estado de Minas Gerais, dentre os municípios analisados, no ano de 2016.

Tabela 7 - Efeitos fixos estimados para o endividamento dos municípios do estado de Minas Gerais

\begin{tabular}{cccc}
\hline Posição & Municípios & PIB em 2016 & $\begin{array}{c}\text { Efeitos fixos estimados para o } \\
\text { grau de endividamento }\end{array}$ \\
\hline 17 & Nova Lima & $7.480 .877,71$ & 7,9942 \\
87 & Uberlândia & $32.536 .256,03$ & 3,2711 \\
95 & Juiz de Fora & $14.532 .952,73$ & 3,0718 \\
114 & Contagem & $26.487 .357,03$ & 2,2473 \\
135 & Belo Horizonte & $88.277 .462,53$ & 1,6180 \\
140 & Betim & $25.144 .473,84$ & 1,5318 \\
144 & Ipatinga & $8.482 .789,91$ & 1,4161 \\
150 & Uberaba & $13.453 .594,31$ & 1,2861 \\
175 & Sete Lagoas & $7.270 .911,68$ & 0,8095 \\
189 & Montes Claros & $8.739 .987,29$ & 0,1414 \\
295 & Silveirânia & $24.789,18$ & $-0,4375$ \\
306 & São Sebastião do Rio Verde & $24.797,84$ & $-0,9248$ \\
422 & Santo Antônio do Rio Abaixo & $20.409,13$ & $-4,3428$ \\
446 & Consolação & $26.447,53$ & $-5,4308$ \\
466 & Grupira & $26.430,97$ & $-6,1243$ \\
492 & Wenceslau Braz & $24.918,89$ & $-6,8396$ \\
500 & Carmésia & $25.693,31$ & $-7,2250$ \\
512 & Pedro Teixeira & $22.372,52$ & $-7,9210$ \\
516 & Cedro do Abaeté & $21.783,58$ & $-8,3838$ \\
518 & Passabém & $18.927,53$ & $-8,5216$ \\
\hline
\end{tabular}

Fonte: Resultados da pesquisa.

A análise dos efeitos fixos estimados permite comparar o nível de endividamento de duas cidades, já que pressupõe que as variáveis explicativas se mantenham em condições idênticas ou constantes. Nesse caso, é possível analisar o seu efeito individual ou a sua heterogeneidade individual. Assim, um município com efeito fixo estimado com sinal positivo apresentaria um endividamento acima da média dos municípios analisados. No caso dos municípios com efeito fixo estimado de sinal negativo, o seu endividamento estaria abaixo da média. 
Na Tabela 7 são descritos os efeitos fixos estimados dos dez municípios com os maiores e menores PIB de 2016. É possível identificar um padrão entre os municípios analisados dentre aqueles com maiores valores do PIB, que tende a ter efeitos fixos estimados maiores e positivos. Resultado inverso ocorreu entre os municípios com menores valores de PIB, visto que seus efeitos fixos estimados foram menores e/ou negativos. Todavia, não significa que o município com maior PIB tenha o maior efeito fixo, como é o caso de Nova Lima. Uma situação semelhante é observada entre os grupos que apresentaram menores valores para o PIB, como é o caso do município de Carmésia. Esses resultados reforçam a heterogeneidade da amostra.

Diante do resultado de que o porte populacional do município não obteve associação significativa em relação ao grau de endividamento público municipal, considerando as demais variáveis explicativas constantes, pode-se supor que os efeitos fixos estão representados de forma compensatória, ou seja, por condições determinísticas, municípios com maiores valores para o PIB apresentariam grau de endividamento acima dos municípios de menores valores para o PIB. Logo, os municípios que apresentam maiores valores para o PIB seriam também aqueles que possuem maiores níveis de arrecadação fiscal, bem como municípios mais propensos a investimentos e maiores endividamentos.

Assim, no geral, os resultados indicam que o desenvolvimento econômico é fator determinante do grau de endividamento dos municípios de Minas Gerais analisados no intervalo de tempo de 2005 a 2016. Este cenário confirma a relação encontrada entre a participação da receita tributária do município e a receita total: quanto maior é a proporção de recursos próprios, maior a tendência dos municípios de estarem mais endividados, controlado pela dummies populacionais.

\section{CONCLUSÕES}

Desde a promulgação da Constituição Federal de 1988, marco da descentralização no Brasil, os entes federativos passaram a enfrentar dificuldades para manter o equilíbrio físcal, o que desencadeou um crescente endividamento público. O aumento do endividamento implica em maiores dispêndios para custear a dívida, consequentemente, menores recursos para investimentos e prestação de serviços à sociedade.

Posto isso, o presente trabalho teve como objetivo verificar a relação entre variáveis financeiras com o grau de endividamento de municípios do estado de Minas Gerais. Foram coletados dados secundários nas bases de dados do Finbra e do IMRS/FJP, compreendendo o período de 2005 a 2016. Por meio da aplicação da técnica de dados em painel com estimação em efeitos fixos, foi possível verificar a relação de indicadores financeiros (participação da receita tributária, da receita de transferência em relação à receita total do município, entre outros) com o grau de endividamento público dos municípios. Além disso, os municípios foram classificados quanto ao porte populacional e quanto ao grau de endividamento.

Os resultados apontaram que as variáveis de estrutura de receitas (PRT e PRFPM) afetam positivamente o grau de endividamento dos municípios do estado de Minas Gerais. A relação positiva da variável PRT contraria estudos que concluem que um aumento na arrecadação própria reflete negativamente o endividamento. Esperava-se que os municípios que apresentassem uma maior relação das receitas próprias seriam os municípios menos propensos ao endividamento. No entanto, essa relação encontrada pode ser justificada pelo aumento de demandas sociais. Municípios que apresentam um maior desempenho fiscal seriam também aqueles com maior volume de gastos devido às pressões da população com o poder executivo. Quanto à variável PRFPM, a relação encontrada confirma a literatura, que pressupõe que os municípios dependentes de repasses do Governo são mais propensos a endividamentos, isso porque estariam mais suscetíveis às aquisições de dívidas para atender às demandas sociais. As variáveis de estrutura de receitas (PICMS e PTV) não foram estatisticamente significativas. Desse modo, os gestores municipais estariam utilizando os recursos próprios e também os adquiridos por meio das transferências intergovernamentais para prover 
serviços à população. De outra forma, o aumento desses recursos na estrutura financeira do município implicaria em menor endividamento público.

As variáveis de estrutura de gastos (GP e DI) afetaram positivamente o endividamento dos municípios. Com isso, municípios que apresentam maior volume de gastos com pessoal e com despesas de investimentos são os municípios mais propensos ao endividamento, visto que parte considerável dos recursos estará comprometida com tais áreas. Ainda, a despesa com investimento foi o indicador que mais afetou o grau de endividamento dos municípios, ou seja, essa variável possui forte influência no nível de endividamento do município. Isso pode ser explicado por causa da natureza da conta de despesas de investimento, pois estes tipos de dispêndios são financiados, geralmente, por operações de crédito de longo prazo, visando à distribuição do benefício e do ônus dos investimentos. Esse fator faz com que ocorra um aumento no grau de endividamento. Além dessas variáveis, o indicador GE t-1 (endividamento defasado) apresentou relação positiva e significativa com o endividamento municipal, ou seja, quanto maior no nível de endividamento do exercício anterior, mais propenso estará o município a aquisição de novos endividamentos nos exercícios subsequentes.

Quanto ao tamanho dos municípios, medido pelo número de habitantes, foi possível observar que o porte populacional não apresenta relação significativa com o endividamento. Isso é confirmado pela estratificação de endividamento municipal proposta neste estudo, onde 76,3\% dos municípios analisados no período temporal de 2005 a 2016 foram classificados no estrato de baixo endividamento, ou seja, municípios de diferentes portes populacionais compõem o mesmo estrato. A estratificação aqui proposta teve como motivação a falta de segregações para os níveis de endividamento, além do limite estabelecido pelo Senado Federal, este que é considerado muito acima da capacidade de endividamento dos municípios, visto que ignora as disparidades existentes entre eles (como por exemplo, a capacidade de geração de receita e o tamanho populacional). Sugere-se que a estratificação seja utilizada para municípios de outros estados, visando identificar a existência de distinção com relação ao grau de endividamento e o porte populacional.

Além disso, os resultados permitiram constatar uma tendência de aumento do grau de endividamento dos municípios do estado de Minas Gerais para o período de 2005 a 2016. Essa tendência de crescimento fica clara ao observar que, em 2005, 46,3 dos municípios apresentaram-se no estrato não endividado (possuíam recursos financeiros para cobrir a dívida), ao passo que a partir de 2009 nenhum município se enquadrou neste estrato.

No entanto, apenas três municípios foram classificados com alto grau de endividamento, estabelecido em $80 \%$ no presente estudo. Este resultado confirma a ideia de que o limite estabelecido pelo Senado Federal de 1,2 para a relação DCL/RCL de governos municipais está muito acima do percentual utilizado pelos municípios do estado de Minas Gerais. Com isso, a LRF não estaria exercendo seu papel de limitador ao endividamento público, uma vez que este está muito acima do percentual utilizado pelos municípios, o que abriria margem para aquisição de novas dívidas. Desse modo, fica evidente a necessidade de alteração do limite de endividamento público dos municípios. Portanto, devem-se estabelecer limites diferentes conforme aspectos populacionais, de renda e capacidade de geração de receita.

Entende-se que o endividamento público é tema relevante e deve ser estudado em todas as esferas (Federal, Estatual e Municipal). No entanto, quando a esfera de análise é a municipal, se torna mais preocupante em municípios de maior porte populacional. Devido à maior facilidade de acesso ao mercado financeiro, estes municípios se revelam mais propensos à aquisição de novos endividamentos.

Assim, para estudos futuros, sugere-se a análise do endividamento dos grandes municípios por macrorregiões brasileiras, visto que o Brasil apresenta enormes disparidades econômicas e geográficas que refletem diretamente na gestão do endividamento municipal. 


\section{REFERÊNCIAS}

Albaladejo, F. J. B., \& López, B. B. (2005). Análisis del endeudamiento en los Ayuntamientos: un Estudio Empírico. Revista Española de Financiación y Contabilidad, 34(126), 613-635.

Baião, A. L. (2013). O papel das transferências intergovernamentais na equalização fiscal dos municípios brasileiros (Dissertação de Mestrado). Fundação Getúlio Vargas, Programa da PósGraduação em Administração Pública e de Empresas, Rio de Janeiro.

Banco Central do Brasil. (2019). Nota para a impressa. Disponível em: <https://www.bcb.gov.br/estatisticas/estatisticasfiscais>.

Brasil. (1964). Lei $\mathbf{n}^{\mathbf{0}} \mathbf{4 . 3 2 0}$, de 17 de março de 1964. Estatui normas gerais de direito financeiro para elaboração e controle dos orçamentos e balanços da União, dos Estados, dos Municípios e do Distrito Federal. Disponível em: 〈http://www.planalto.gov.br/ccivil_03/leis/L4320.htm>.

Brasil. (2000). Lei Complementar $\mathbf{n}^{\mathbf{0}} \mathbf{1 0 1}$, de 4 de maio de 2000. Estabelece normas de finanças públicas voltadas para a responsabilidade na gestão fiscal e dá outras providências. Disponível em: <http://www.planalto.gov.br/ccivil_03/Leis/LCP/Lcp101.htm>.

Brasil. (2001). Resolução no 40, de 20 de dezembro de 2001. Dispõe sobre os limites globais para o montante da dívida pública consolidada e da dívida pública mobiliária dos Estados, do Distrito Federal e dos Municípios, em atendimento ao disposto no art. 52, VI e IX, da Constituição Federal. Disponível em: <http://www6.senado.gov.br/legislacao/ListaPublicacoes.action?id=234173\&tipo Documento=RSF\&tipoTexto=ATU $>$.

Brasil.(1988). Constituição (1988). Constituição da República Federativa do Brasil de 1988. Disponível em: <http://www.planalto.gov.br/ccivil_03/constituicao/constituicaocompilado.htm>.

Carvalho, J. R. M., de Oliveira, G. F., \& Santiago, J. S. (2010). Dívida Pública: Um Estudo de Indicadores dos Estados Nordestinos. Revista Universo Contábil, 6(2), 82-100.

Cavalcanti, M. C. B.(2006). Análise dos tributos incidentes sobre os combustíveis automotivos no Brasil (Dissertação de Mestrado). Universidade Federal do Rio de Janeiro, Programa de Pós-Graduação em Planejamento Energético, Rio de Janeiro.

Corbari, E. C. (2008). Grandes municípios brasileiros: estrutura do endividamento e impactos da Lei de Responsabilidade Fiscal (Dissertação de Mestrado). Universidade Federal do Paraná, Programa de Pós-Graduação em Contabilidade, Curitiba.

Costa, J. F. (2008). Reflexos da Lei de Responsabilidade Fiscal no endividamento dos municípios brasileiros. In Anais, XVIII Congresso Brasileiro de Contabilidade, Gramado - RS.

Fávero, L. P. (2015). Análise de dados: modelos de regressão com Excel, Stata e SPSS. Elsevier, São Paulo.

Fernandes, C. G. (2010). Determinantes do endividamento autárquico: evidência empírica para os municípios portugueses utilizando modelo de dados de painel (Dissertação de Mestrado). Universidade da Beira Interior, Programa de Pós-Graduação em Economia, Covilhã.

Ferreira, A. C., Araujo, J. M., Barros, R. G., Viana, R. F. C., \& Reis, F. A. (2013). Fatores determinantes do endividamento dos estados brasileiros uma análise de 200 a 2010. In Anais, $8^{\circ}$ SOBER Nordeste, Sociedade Brasileira de Economia, Administração e Sociologia Rural Paraíba.

Fundação João Pinheiro. (2011). Produto Interno Bruto de Minas Gerais. Centro de Estatística e Informações. Relatório Anual.

Garselaz, P. S. (2000). Dívida pública: uma abordagem teórica, um relato histórico e o caso do Rio Grande do Sul (Dissertação de Mestrado). Universidade Federal do Rio Grande do Sul, Programa de Pós-Graduação em Administração Pública, Porto Alegre.

Giambiagi, F., \& Além, A. C. (2000). Finanças públicas: teoria e prática no Brasil, 2. ed. Rio de Janeiro: Campus.

Gremaud, A. P., \& Toneto Junior, R. (2002). Descentralização e endividamento municipal: formas, limites e possibilidades. Nova Economia, 12(2), 109-130.

Gujarati, D. (2006). Econometria básica. Editora: Campus.

Instituto Brasileiro de Geografia e Estatística (2010). Censo Demográfico 2010. Disponível em: <https://ww2.ibge.gov.br/home/estatistica/populacao/censo2010/default.shtm>.

Lima, S. C. (2011). Desempenho fiscal da dívida dos grandes municípios brasileiros (Tese de Doutorado). Universidade de São Paulo, Programa de Pós-Graduação em Controladoria e Contabilidade, São Paulo. 
Linhares, F., Penna, C., \& Borges, G. (2013). Os efeitos da Lei de Responsabilidade Fiscal no endividamento dos municípios do Piauí. Revista de Administração Pública, 47(6), 1359-1374.

Macedo, J. J., \& Corbari, E. C. (2009). Efeitos da lei de responsabilidade fiscal no endividamento dos municípios brasileiros: uma análise de dados em painéis. Revista Contabilidade \& Finanças, 20(51), 44-60.

Matias, A. B.; Campello, C. A. G. B. (2000). Administração financeira municipal. São Paulo: Atlas.

Matias-Pereira, J. (2006). Finanças públicas: a política orçamentária no Brasil. 3. ed. São Paulo: Atlas.

Matias-Pereira, J. (2012). Finanças públicas: foco na política fiscal, no planejamento e orçamento público. 6. ed. São Paulo: Atlas.

Mello, G. R., \& Dalchiavon, E. C. (2012). A lei de responsabilidade fiscal (LRF) e o impacto sobre o endividamento dos municípios potiguares. Contextus-Revista Contemporânea de Economia e Gestão, 10(2).

Mello, G. R., \& Slomski, V. (2008). O Endividamento dos Estados Brasileiros: verificação da situação utilizando a Análise Multivariada de Dados. Contabilidade Vista \& Revista, 19(1), 11-35.

Mello, G. R., \& Slomski, V. (2009). Fatores que influenciam o endividamento dos estados brasileiros. Revista de Contabilidade e Organizações, 3(7), 78-92.

Mendes, M. (2002). Descentralização fiscal baseada em transferências e captura de recursos públicos nos municípios brasileiros (Tese de Doutorado). Universidade de São Paulo, Programa de PósGraduação em Economia, São Paulo.

Musgrave, R. A., \& Musgrave, P. B. (1980). Finanças públicas: teoria e prática. São Paulo: Campus.

Nascimento, E. R. (2003). Finanças públicas: união, estados e municípios. 2 ed. Brasília: Vestcon.

Nascimento, E. R., \& Debus, I. (2002). Lei Complementar nº 101/2000: entendendo a Lei de Responsabilidade Fiscal. Revista do Tesouro Nacional, $2^{\circ}$ ed. Atual., 171.

Orair, R. A., \& Alencar, A. A. (2010). Esforço fiscal dos municípios: indicadores de condicionalidade para o sistema de transferências intergovernamentais. Monografia premiada em $1^{\circ}$ lugar no XV Prémio Tesouro Nacional. Tópicos especiais de finanças públicas, Brasília.

Rezende, F. A. (2001). Finanças públicas. 2. ed. - São Paulo: Atlas.

Silva Suzart, J. A. (2013). Dívida dos governos subnacionais brasileiros: uma análise sob a ótica do federalismo fiscal. Administração Pública e Gestão Social, 5(2), 44-53.

Silva, S. M. (2005). Teoria do federalismo fiscal: notas sobre as contribuições de Oates, Musgrave, Shah e ter-Minassian. Nova Economia, 15(1), 117-137.

Siqueira, K. J. S. P. (2014). Esforço fiscal dos municípios pernambucanos: uma análise de fronteira estocástica (Dissertação de Mestrado). Universidade Federal de Pernambuco, Programa de PósGraduação em Economia, Recife.

Soares, C. S., Ceretta, P. S., Coronel, D. A., \& Vieira, K. M. (2013). A Lei de Responsabilidade Fiscal e o Comportamento do Endividamento dos Estados Brasileiros: uma análise de dados em painel de $2000 \mathrm{a}$ 20101. Revista ADMPG, 6(1).

Tristão, A. M. (2003). A administração tributária dos municípios brasileiros: uma avaliação do desempenho da arrecadação (Tese de Doutorado). Fundação Getúlio Vargas, Escola de Administração de Empresas de São Paulo, São Paulo. 